\title{
Anti-diabetic Activity in Mice of Piper Capence Used Traditionally in the Management of Diabetes Mellitus in Kenya
}

\section{Njeri LK* and Eliud NM Njagi}

Department of Biochemistry and Biotechnology, School of Pure and Applied Sciences, Kenyatta University, P.O. Box 43844-00100, Nairobi, Kenya

*Corresponding author: Njeri L Kimani, Department of Biochemistry and Biotechnology, School of Pure and Applied Sciences, Kenyatta University, P.O. Box 43844-00100, Nairobi, Kenya, Tel: +254724657349; E-mail: lucy3kimani@yahoo.com

Received date: April 08, 2017; Accepted date: April 24, 2017; Published date: April 30, 2017

Copyright: @ 2017 Njeri LK, et al. This is an open-access article distributed under the terms of the Creative Commons Attribution License, which permits unrestricted use, distribution, and reproduction in any medium, provided the original author and source are credited.

\begin{abstract}
Diabetes mellitus causes significant morbidity, mortality, and diabetes related complications. Conventional drugs are used in management of diabetes mellitus but are costly, are not readily available and also have many side effects. Herbal plants used in diabetes mellitus management are believed to be cheaper and readily available. Piper capense is used traditionally in diabetes mellitus management but its efficacy has to be scientifically evaluated. The study's aim was to investigate antidiabetic potential of aqueous root extracts of Piper capense in diabetic male albino mice. The antidiabetic potential of the extracts was screened in diabetic mice using oral as well as intraperitoneal routes. In the study, albino mice were put into eight groups comprising five mice each. For this purpose aqueous extract was administered at $25,48.4,93.5,180.9$, and $350 \mathrm{mg} / \mathrm{kg}$ body weight. $1 \mathrm{lU} / \mathrm{kg}$ body weight dose of insulin and $4.6 \mathrm{mg}$ of glibenclamide was used as a standard hypoglycemic agent for comparing the results. Blood sugar levels were measured at 2, 4, 6, 8, 10 and 24 hours with the use of a glucometer. The data was then analyzed using ANOVA and post-ANOVA. The lyophilate of Piper capense phytochemical composition was determined by standard procedures. Piper capense extracts administered by either route at $25 \mathrm{mg} / \mathrm{kg}$ body weight, $48.4 \mathrm{mg} / \mathrm{kg}$ body weight, $93.5 \mathrm{mg} / \mathrm{kg}$ body weight, $180.9 \mathrm{mg} / \mathrm{kg}$ body weight and $350 \mathrm{mg} / \mathrm{kg}$ body weight showed antidiabetic activity. The phytochemical result showed that the aqueous extracts contained tannins, flavonoids, alkaloids, sterols, and saponins. The antidiabetic activity showed could be due to the presence of some phytochemicals present which have antidiabetic activity.
\end{abstract}

Keywords: Diabetes mellitus; Hypoglycemic activity; Piper capense; in vivo; Antidiabetic activity; IU (Insulin units); Glibenclamide

\section{Introduction}

Diabetes mellitus has many causes and is characterized by high blood sugar level. The observed hyperglycemia is due to interferance in metabolism of protein, carbohydrate and fat due to impaired secretion and action of insulin [1]. Diabetes mellitus is characterized by excessive blood glucose due to insufficient insulin production in the pancreas or by the inability of the produced insulin to control blood glucose [2]. Hyperglycemia leads to severe consequences such as amputations, brain damage and diseases of the heart [3]. About 171 million people worldwide had diabetes in 2000 and this is expected to increase to 366 million people by the year 2030 [4].

Diabetes is diagnosed clinically by the presence of polyuria, weight loss and polydipsia. Diabetes mellitus is confirmed by abnormal blood glucose level [4]. Normally fasting plasma sugar levels range between 3.5-6.7 mmol/l. Fasting plasma glucose levels repeatedly at $\geq 7.0$ $\mathrm{mmol} / \mathrm{L}(126 \mathrm{mg} / \mathrm{dl})$ confirms diabetes [5]. The treatment of DM is based on oral hypoglycemic agents and insulin injections. The hypoglycemic agents currently used in clinical practice have characteristic profiles of adverse side effects [6]. Diabetes mellitus management with insulin causes side effects such as such as resistance of insulin, atrophy of brain, anorexia nervosa, and fatty liver after a long time of treatment. Therefore, due to the side effects there is need to come up with effective, safe and readily availlable antidiabetic drugs. Medicinal plants can therefore provide the effective, safe and cheap drugs [7]. Plants contain many bioactive compounds and therefore they are a possible source of different types of drugs [8]. A number of traditional plants have been reported to have antidiabetic effect. For instance, Pappea capensis and Pterocarpus marsupium has long histories of use in treatment of diabetes mellitus [9]. Ginkgo biloba extract has proved useful for prevention and treatment of early-stage diabetic neuropathy [10].

Among the traditionally used plants in the diabetes mellitus management in Gilgil Nakuru county Kenya is Piper capense. The Piper genus is an important medicinal plant in the tropical region [11]. Volatile oil from Piper capense has been reported to show inhibitory effect of the tumor cells, antioxidant and antimicrobial activity [12]. However, there is limited scientific evidence regarding the antidiabetic efficacy profiles to back up the continued therapeutic application of this herbal remedy. This study provides the knowledge on the use of Piper capense in the diabetes mellitus management that will go a long way in validating its folkloric usage.

\section{Material and Methods}

\section{Study site}

This study site was at the Department of Biochemistry and Biotechnology, School of Pure and Applied Sciences, Kenyatta University in 2016.

\section{Collection of plant materials}

Collection of the roots of Piper capense was done in Gilgil division of Naivasha district in Nakuru County, Kenya. This collection was 
guided on the information from practicing herbalists on antidiabetic activity of Piper capense. Identification of the plant was done at the at the National Museum of Kenya herbarium.

\section{Processing of plant}

The roots were cut into pieces which were air-dried under shed for one month. Dried materials were then ground into powder using of an electric mill. The powder was kept in plastic bags away from sunlight.

\section{Preparation of aqueous plant extracts}

A hundred grams powdered roots were extracted in 1 litre of water at $60^{\circ} \mathrm{C}$ for about 6 hours. The metabolic shaker was used for this extraction. Cooling of the mixture was natural and on cooling it was decanted over folded cotton gauze staffed in a funnel into a conical flask. Freeze drying of the filtrate was done for 72 hours. The concentrated extract was stored in an air tight sample bottle at $-20^{\circ} \mathrm{C}$.

\section{Experimental animals}

The Albino mice of 3-4 weeks old and weighing 22-27 g were used in the study. The mice were fed on rodent pellets and water ad libitum. Protocols and procedures of experiment were approved.

\section{Induction of diabetic}

During the experiment mice were fasted for at least 8-12 hours but were given water. Diabetes was induced by administration of 186.9 $\mathrm{mg} / \mathrm{kg}$ weight of $10 \%$ alloxan monohydrate intraperitoneally. The control animals were administered normal saline intrperitonially. At 48 hours after induction of diabetes blood sugar level was measured with a glucometer. Only those mice which were considered diabetic (blood glucose $>2000 \mathrm{mg} / \mathrm{L}$ or $>11.1 \mathrm{mmol}$ per litre) were included for this study.

\section{Experimental design}

Eight groups of five animals each were used as labelled below:

Group I - Normal mice administered intraperitoneally or orally with $0.1 \mathrm{ml}$ physiological saline.

Group II - Alloxan induced diabetic animals administered intraperitoneally or orally with $0.1 \mathrm{ml}$ physiological saline.

Group IIIa - Alloxan induced diabetic animals administered inntraperitoneally with 0.12 units of insulin in $0.1 \mathrm{ml}$ physiological saline.

Group IIIb - Alloxan induced diabetic mice orally administered with $4.6 \mathrm{mg}$ of glibenclamide $(200 \mathrm{mg} / \mathrm{kg}$ body weight) in $0.1 \mathrm{ml}$ physiological saline.

Group IV - Alloxan induced diabetic animals administered intraperitoneally or orally with $0.575 \mathrm{mg}$ extract in $0.1 \mathrm{ml}$ physiological saline ( $25 \mathrm{mg} / \mathrm{kg}$ body weight).

Group V - Alloxan induced diabetic animals administered intraperitoneally or orally with $1.11 \mathrm{mg}$ extract in $0.1 \mathrm{ml}$ physiological saline (48.4 mg/kg body weight).

Group VI - Alloxan induced diabetic animals administered intraperitoneally or orally with $2.15 \mathrm{mg}$ extract in $0.1 \mathrm{ml}$ physiological saline ( $93.5 \mathrm{mg} / \mathrm{kg}$ body weight).
Group VII - Alloxan induced diabetic animals administered intraperitoneally or orally with $4.16 \mathrm{mg}$ extract in $0.1 \mathrm{ml}$ physiological saline $(180.9 \mathrm{mg} / \mathrm{kg}$ body weight).

Group VII - Alloxan induced diabetic animals administered intraperitoneally or orally with $8.06 \mathrm{mg}$ extract in $0.1 \mathrm{ml}$ physiological saline ( $350 \mathrm{mg} / \mathrm{kg}$ body weight).

\section{Blood sampling, blood glucose, rate constant and half-life determination}

Samples of blood were obtained from the tail after sterilizing it with alcohol. The tail was nibbed and drops of blood squeezed into a glucometer. The samples were collected at the beginning of the experiment and repeated at intervals of 2, 4, 6, 8, 10 and 24 hours. Rate constant (k) was determined by a plot of log blood glucose concentration of first 4 hours against time (in hours). The plot gave pseudo-first order rate constant $(\mathrm{k} / 2.303)$. The constant is indicated by the point where straight line intersects logarithm of blood sugar concentration axis (This showed the sugar concentration before administration of the drug) [13]. Calculation of the half-life was done by substituting constant $(\mathrm{k})$ in formulae: $\mathrm{t}_{0.5}=0.693 / \mathrm{k}$. Half-life refers to the time taken to reduce blood glucose level by half for a given dosage [14]. The equation of exponential decay was used to determine the dosage which would be given after a given period [15].

\section{Screening of phytochemicals}

Standard methods were used to determine the phytochemical of alkaloids, flavonoids, saponins, tannins, and sterols present in Piper capense extracts $[16,17]$.

\section{Management of data and statistical analysis}

Data was put in Microsoft Excel and after cleaning exported to Statistical Package of Social Sciences (SPSS) software where analysis was done. Results were given as Mean \pm SD (standard deviation) of number of mice used in a study group. Analysis was done with use of ANOVA and also post-ANOVA which compared the means of normal control animals with diabetic animals administered with saline, diabetic animal's adminisered with conventional drugs, diabetic animals administered with plant extracts at 25, 48.4, 93.5, 180.9, and $350 \mathrm{mg} / \mathrm{kg}$ body weight. $\mathrm{P} \leq 0.05$ was considered to be statistically significant.

\section{Effects of oral and intraperitoneal administration of Piper capense extracts on blood glucose levels in alloxan induced diabetic mice}

Administration by oral route of Piper capense aqueous extracts of at $25,48.4,93.5,180.9$, and $350 \mathrm{mg}$ per kilogram body weight in mice decreased the blood sugar levels significantly from the $2^{\text {nd }}$ hour through to the $8^{\text {th }}$ hour without regard to the amount of dose given. The percentage reductions of blood sugar levels in mice by the aqueous root extract of Piper capense at the five dose levels (25, 48.4, 93.5, 180.9 , and $350 \mathrm{mg}$ per kilogram body weight) during the $2^{\text {nd }}$ hour was $47.8 \%, 57.2 \%, 58.7 \%, 57.5 \%$ and $47.4 \%$, respectively, compared to glibenclamide administered diabetic mice whose plasma glucose levels was decreased to $71.7 \%$ within the second hour (Figure 1 ). At the $2^{\text {nd }}$ hour the plant root extract decreased the blood sugar levels but the attained levels were not normal $\left({ }^{\mathrm{d}} \rho<0.05\right)$ (Table 1$)$. The doses, 
Citation: Njeri LK, Njagi ENM (2017) Anti-diabetic Activity in Mice of Piper Capence Used Traditionally in the Management of Diabetes Mellitus in Kenya. J Diabetes Metab 8: 737. doi:10.4172/2155-6156.1000737

Page 3 of 6

however, significantly decreased blood sugar levels in comparison to diabetic control $\left({ }^{\mathrm{a}} \rho<0.05\right)$ (Table 1$)$.

\begin{tabular}{|c|c|c|c|c|c|c|c|}
\hline \multirow{2}{*}{ Treatment } & \multirow{2}{*}{ Route } & \multicolumn{6}{|c|}{ Glucose Levels at Varying Times $(\mathrm{mm} / \mathrm{L})$} \\
\hline & & $0 \mathrm{hr}$ & $2 \mathrm{hr}$ & $4 \mathrm{hr}$ & $6 \mathrm{hr}$ & $8 \mathrm{hr}$ & $24 \mathrm{hr}$ \\
\hline Group I & IP & $5.26 \pm 0.05$ & $5.32 \pm 0.06^{\mathrm{BFGH}}$ & $5.36 \pm 0.05^{\mathrm{BDEFGH}}$ & $5.22 \pm 0.37^{\mathrm{BDEFGH}}$ & $5.30 \pm 0.04^{\mathrm{BDEFG}}$ & $5.32 \pm 0.05^{\mathrm{BGH}}$ \\
\hline (Normal saline) & Oral & $5.18 \pm 0.04$ & $5.18 \pm 0.04^{\mathrm{efhi}}$ & $5.20 \pm 0.03^{\text {efghi }}$ & $5.16 \pm 0.02^{\text {befgh }}$ & $5.20 \pm 0.03^{\text {begh }}$ & $5.22 \pm 0.04^{\mathrm{bghi}}$ \\
\hline Group II & IP & $14.70 \pm 1.08^{\mathrm{BDEFGH}}$ & $15.86 \pm 1.13$ & $17.14 \pm 1.27$ & $18.58 \pm 1.34$ & $20.18 \pm 1.32$ & $23.60 \pm 1.54$ \\
\hline (Diabetic) & Oral & $13.42 \pm 0.95^{\text {befghi }}$ & $14.76 \pm 0.76 b$ & $16.20 \pm 0.65$ & $17.34 \pm 0.61$ & $19.26 \pm 0.62$ & $21.66 \pm 1.14$ \\
\hline Group IIla (Insulin) & IP & $14.40 \pm 0.67^{\mathrm{ADEFGH}}$ & $6.32 \pm 0.27^{\mathrm{CEFGH}}$ & $5.94 \pm 0.20 C^{D E F G H}$ & $5.42 \pm 0.16^{\mathrm{CDEFGH}}$ & $5.10 \pm 0.11$ CDEFG & $6.82 \pm 0.20^{\mathrm{CEFGH}}$ \\
\hline $\begin{array}{l}\text { Group } \\
\text { (Glibenclamide) }\end{array}$ & Oral & $15.60 \pm 1.33^{\text {aefghi }}$ & $11.18 \pm 1.67^{\text {agh }}$ & $8.10 \pm 0.87 \mathrm{~h}$ & $6.38 \pm 0.41 \mathrm{deh}$ & $5.18 \pm 0.12^{\mathrm{degh}}$ & $8.18 \pm 0.83^{\text {defghi }}$ \\
\hline \multicolumn{8}{|l|}{ Extract } \\
\hline Group IV & IP & $14.30 \pm 0.69^{A B D E F G H}$ & $10.06 \pm 0.65^{\mathrm{DEFG}}$ & $7.72 \pm 0.56^{\mathrm{BCDEFG}}$ & $6.42 \pm 0.35^{\text {BCDEFG }}$ & $5.36 \pm 0.25^{\mathrm{BCDEFG}}$ & $10.70 \pm 0.55^{\mathrm{DEFG}}$ \\
\hline (25 mg/kg) & Oral & $13.86 \pm 0.28^{\text {abefghi }}$ & $6.62 \pm 0.78^{\text {defghi }}$ & $5.02 \pm 0.36^{\text {defghi }}$ & $4.50 \pm 0.36^{\text {bdefghi }}$ & $4.16 \pm 0.35^{\text {bdefghi }}$ & $9.82 \pm 0.44^{\text {befghi }}$ \\
\hline Group V & IP & $14.58 \pm 0.67^{\mathrm{ABDEFGH}}$ & $8.12 \pm 0.45^{\mathrm{BDEFGH}}$ & $6.22 \pm 0.46^{\mathrm{BCDEFGH}}$ & $5.08 \pm 0.32^{B C D E F G H}$ & $4.10 \pm 0.45^{\mathrm{BCDEFGH}}$ & $9.62 \pm 0.47^{\mathrm{BDEFG}}$ \\
\hline$(48.4 \mathrm{mg} / \mathrm{kg})$ & Oral & $11.88 \pm 1.85^{\text {abefghi }}$ & $6.80 \pm 0.74^{\text {defghi }}$ & $5.16 \pm 0.62^{\text {defghi }}$ & $3.96 \pm 0.45^{\text {defghi }}$ & $3.24 \pm 0.31^{\text {efghi }}$ & $9.40 \pm 0.43^{\text {befghi }}$ \\
\hline Group VI & IP & $14.42 \pm 0.47^{-\mathrm{BDEFGG}}$ & $8.00 \pm 0.14 \mathrm{BCDEFGH}$ & $5.46 \pm 0.43^{\text {BCDEFGH }}$ & $4.40 \pm 0.40^{B C D E F G H}$ & $3.36 \pm 0.20^{\mathrm{BCDEFGH}}$ & $8.68 \pm 0.56^{\mathrm{BDEFGH}}$ \\
\hline$(93.5 \mathrm{mg} / \mathrm{kg})$ & Oral & $13.38 \pm 0.37^{\text {abefghi }}$ & $7.86 \pm 0.50^{\text {bdefghi }}$ & $5.44 \pm 0.53^{\text {defghi }}$ & $4.40 \pm 0.35^{\text {defghi }}$ & $3.68 \pm 0.34^{\text {befghi }}$ & $8.38 \pm 0.74^{\text {bdefghi }}$ \\
\hline Group VII & IP & $14.16 \pm 0.6 \AA^{\text {ABDEFGH}}$ & $7.32 \pm 0.51^{\mathrm{BCDEFGH}}$ & $5.16 \pm 0.34^{\mathrm{BCDEFGH}}$ & $4.18 \pm 0.31^{B C D E F G H}$ & $3.48 \pm 0.21^{\mathrm{BCDEFGH}}$ & $8.54 \pm 0.63^{\mathrm{BCDEFGH}}$ \\
\hline (180.9 mg/kg) & Oral & $12.60 \pm 0.72^{\text {abefghi }}$ & $7.24 \pm 0.67^{\text {bdefghi }}$ & $5.56 \pm 0.60^{\text {bdefghi }}$ & $4.78 \pm 0.58^{\text {bdefghi }}$ & $4.14 \pm 0.87^{\text {bdefghi }}$ & $8.40 \pm 0.81^{\text {bdefghi }}$ \\
\hline Group VIII & IP & $13.78 \pm 0.74^{\text {BDEFGH }}$ & $6.70 \pm 0.53^{\mathrm{BCEFGH}}$ & $4.38 \pm 0.20^{\mathrm{BCEFGH}}$ & $3.46 \pm 0.29^{B C E F G H}$ & $2.56 \pm 0.14 \mathrm{EFGH}$ & $5.54 \pm 0.38^{\mathrm{BCFGH}}$ \\
\hline (350 mg/kg) & Oral & $12.28 \pm 0.55^{\text {abefghi }}$ & $5.82 \pm 1.08^{\text {defghi }}$ & $3.70 \pm 0.23^{\text {defghi }}$ & $3.16 \pm 0.28^{\text {efghi }}$ & $2.66 \pm 0.26^{\text {efghi }}$ & $7.10 \pm 0.57^{\text {bdefghi }}$ \\
\hline \multicolumn{8}{|c|}{ 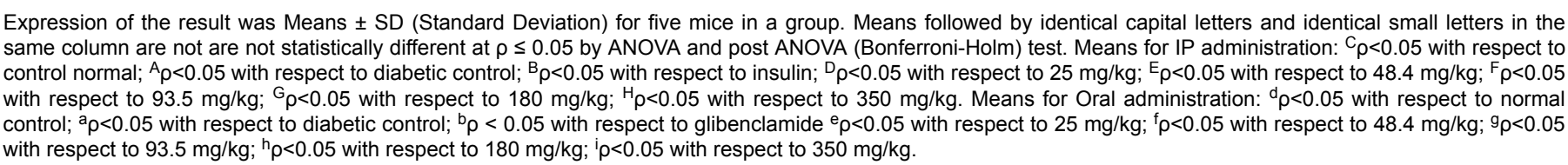 } \\
\hline
\end{tabular}

Table 1: Effects of five doses of aqueous root extracts of Piper capense with time on blood sugar levels in diabetic mice.

During the fourth hour, the sugar decreasing effect of five doses observed was $36.2 \%, 43.4 \%, 40.7 \% 44,1 \%$ and $30.1 \%$, respectively, in comparison to glibenclamide administered diabetic mice whose plasma glucose levels was decreased to $51.1 \%$ within the fourth hour. The extract decreased plasma sugar levels to almost normal $\left({ }^{\mathrm{d}} \rho>0.05\right)$ and even to levels lower than those caused by glibenclamide $\left({ }^{\mathrm{b}} \rho<0.05\right)$. In the $6^{\text {th }}$ hour, the root extract decreased plasma glucose levels by $32.5 \%, 33.3 \%, 32.9 \%, 37.9 \%$ and $25.7 \%$, respectively in comparison to glibenclamide administered diabetic mice whose plasma glucose levels was decreased to $40.9 \%$. At this hour $180.9 \mathrm{mg} / \mathrm{kg}$ extract decreased plasma sugar levels like glibenclamide $\left({ }^{\mathrm{b}} \rho<0.05\right)$. Same trend was shown in the eighth hour when the five doses decreased plasma sugar to levels below that of glibenclamide which decreased to $33.2 \%$. The percentage plasma sugar decrease were $30.0 \%, 27.3 \%, 27.5 \%, 32.9 \%$ and $21.7 \%$, respectively (Figure 1 ).

Administration intraperitoneally of aqueous root extracts of Piper capense at $25,48.4,93.5,180.9$, and $350 \mathrm{mg} / \mathrm{kg}$ body weight to mice significantly decreased the blood glucose levels from the $2^{\text {nd }}$ hour through to the $8^{\text {th }}$ hour in a dose independent manner. The percentage reductions of blood glucose levels in mice by the aqueous extract of Piper capense at the five dose levels $(25,48.4,93.5,180.9$, and 350 $\mathrm{mg} / \mathrm{kg}$ body weight) during the $2^{\text {nd }}$ hour was $70.4 \%, 55.7 \%, 55.5 \%$, $51.69 \%$ and $48.63 \%$, respectively, comparison to insulin administered 
Page 4 of 6

diabetic mice whose plasma glucose levels was lowered to $43.89 \%$ within the second hour (Figure 2). The percentage reduction was however significant compared diabetic control group $\left({ }^{\mathrm{A}} \rho<0.05\right)$ (Table 1).

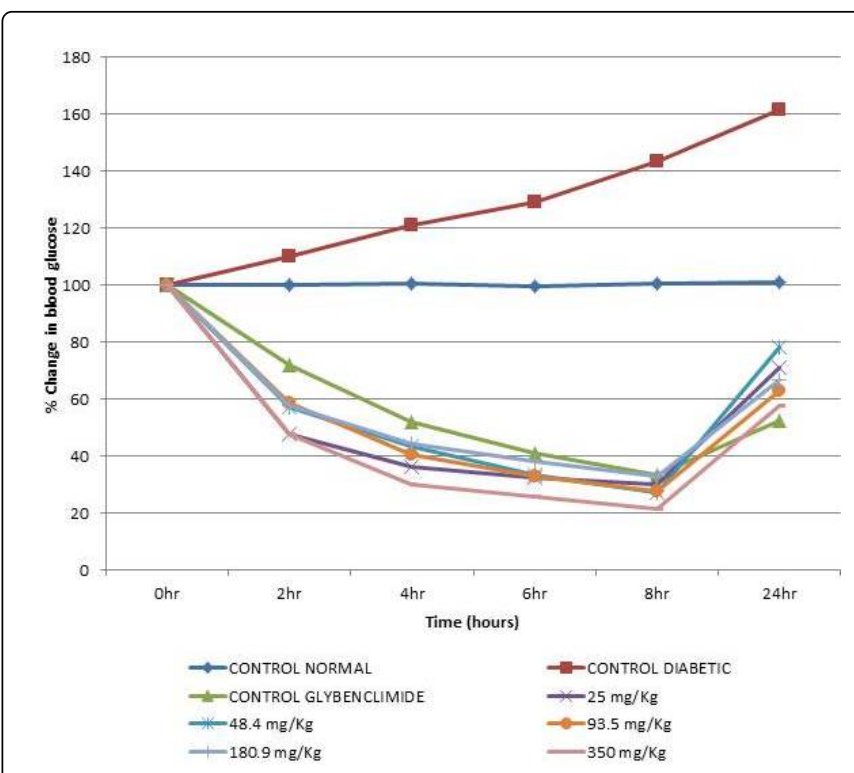

Figure 1: Percentage decrease in plasma sugar levels at different times after administration of plant root extracts of Piper capense orally at $25,48.4,93.5,180.9$, and $350 \mathrm{mg}$ per kilogram body weight in diabetic male mice.

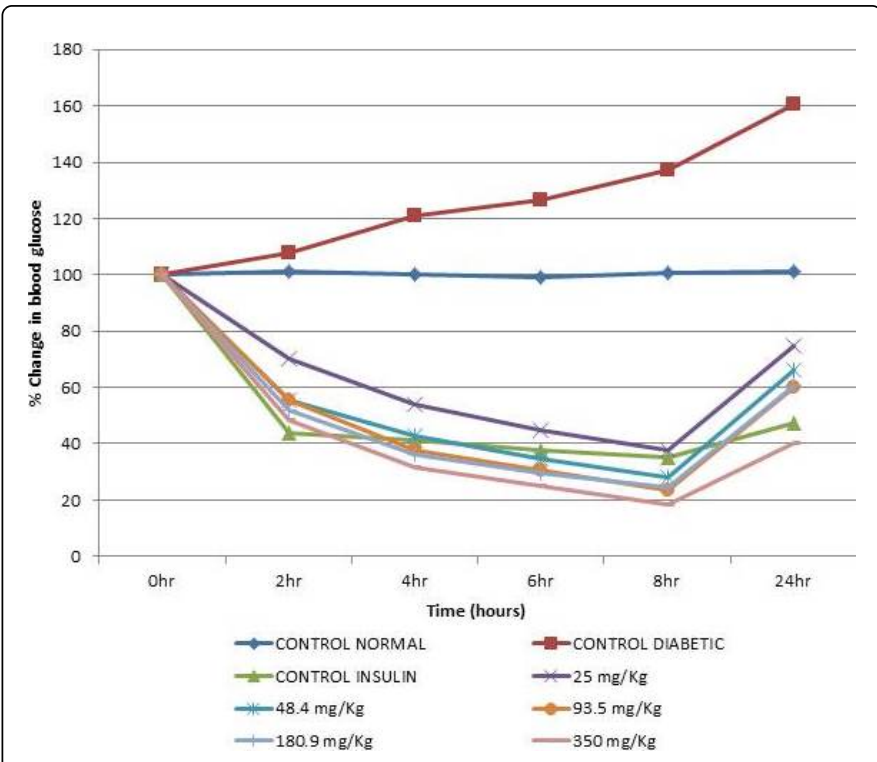

Figure 2: Percentage decrease in plasma sugar levels at different times after administration of plant root extracts of Piper capense intraperitoneally at $25,48.4,93.5,180.9$, and $350 \mathrm{mg}$ per kilogram body weight in diabetic male mice.

During the 4th hour, the glucose lowering effect by the five dose levels was also observed; the reduction by percentages of plasma sugar levels were $54,0 \%, 42.7 \%, 37.9 \% 36.4 \%$ and $31.8 \%$, respectively, comparison to insulin administered diabetic animals whose plasma glucose levels was decreased to $41.3 \%$ within the fourth hour. The extract lowered blood glucose levels to normal $\left({ }^{C} \rho>0.05\right)$. In the $6^{\text {th }}$ hour, the extract lowered blood glucose levels by $44.9 \%, 34.8 \%, 30.5 \%$, $29.5 \%$ and $25.1 \%$, respectively, in comparison to insulin administered diabetic mice whose plasma glucose levels was decreased to $37.64 \%$. At this hour $48.4 \mathrm{mg} / \mathrm{kg}$ extract lowered blood glucose levels as effectively as insulin $\left({ }^{\mathrm{B}} \rho<0.05\right)$. Similar behaviour was observed during the eighth hour when the five dosages decreased plasma sugar level to levels below those of insulin which decreased glucose by $35.4 \%$. The percentage blood glucose reductions were $37.5 \%, 28.1 \%, 23.3 \%, 24.6 \%$ and $18.6 \%$, respectively (Figure 2).

Table 2 shows the pharmacokinetics of antidiabetic activity for the 1 st 4 hours of root extracts of Piper capense. Pseudo-first order rate constants for the oral administration of root extract Piper capense at $25 \mathrm{mg} / \mathrm{kg}, 48.4 \mathrm{mg} / \mathrm{kg}, 93.5 \mathrm{mg} / \mathrm{kg}, 180.9 \mathrm{mg} / \mathrm{kg}$ and $350 \mathrm{mg} / \mathrm{kg}$ were $0.5078,0.417,0.45,0.409$ and 0.5998 , respectively, and their accompanying half-lifes were 1.36, 1.66, 1.54, 1.69, and 1.16, respectively. The observed half-lifes were lower than those of glibenclamide.

\begin{tabular}{|c|c|c|c|}
\hline Drug (dose) & Route & $\begin{array}{l}\text { Rate constant } \\
\left(\text { hour }^{-1} \text { ) }\right.\end{array}$ & $\begin{array}{l}\text { Half-life } \\
\text { (hours) }\end{array}$ \\
\hline Insulin & IP & 0.4428 & 1.57 \\
\hline Glibenclamide & Oral & 0.3277 & 2.11 \\
\hline \multicolumn{4}{|c|}{ Extract (mg per kilogram body weight) } \\
\hline \multirow{2}{*}{25} & IP & 0.3082 & 2.25 \\
\hline & Oral & 0.5078 & 1.36 \\
\hline \multirow{2}{*}{48.4} & IP & 0.417 & 1.66 \\
\hline & Oral & 0.417 & 1.66 \\
\hline \multirow{2}{*}{93.4} & IP & 0.4856 & 1.43 \\
\hline & Oral & 0.45 & 1.54 \\
\hline \multirow{2}{*}{180.9} & IP & 0.4783 & 1.45 \\
\hline & Oral & 0.409 & 1.69 \\
\hline \multirow{2}{*}{350} & IP & 0.5731 & 1.21 \\
\hline & Oral & 0.5998 & 1.16 \\
\hline
\end{tabular}

Table 2: Pharmacokinetics of antidiabetic activity for the 1st 4 hours of the 5 doses of the aqueous root extracts of Piper capense.

Pseudo-first order rate constants for the intraperitoneal administration of doses of the aqueous root extracts of Piper capense at $25 \mathrm{mg} / \mathrm{kg}, 48.4 \mathrm{mg} / \mathrm{kg}, 93.5 \mathrm{mg} / \mathrm{kg}, 180.9 \mathrm{mg} / \mathrm{kg}$ and $350 \mathrm{mg} / \mathrm{kg}$ were $0.3082,0.417,0.4856,0.4783$ and 0.5731 , respectively, and their accompanying half-lifes were $2.25,1.66,1.43,1.45$ and 1.21 , respectively. The half-lifes of $25 \mathrm{mg} / \mathrm{kg}$, and $48.4 \mathrm{mg} / \mathrm{kg}$ doses were higher than those of insulin while those of the other doses were lower. The rate constants for the orally administered aqueous extracts of $P$. capense for the five doses ranged from 0.409 to 0.5998 per hour and the half-lifes ranged from 1.69 to 1.69 hours, respectively. Rate constants for the intraperitoneally administered aqueous extracts of $P$. 
capense for the five doses ranged from 0.3082 to 0.5731 per hour and the half-lifes ranged from 2.25 to 1.21 hours, respectively. The rate constant for insulin was 0.4428 per hour and that of glibenclamide was 0.3277 per hour while their corresponding half-lifes were 1.57 and 2.11 hours, respectively.

\section{Quanitative analysis of the phytochemical present of aqueous root extracts of Piper capense}

\begin{tabular}{|c|c|c|c|c|c|}
\hline \multirow{2}{*}{ Sample } & \multicolumn{4}{|c|}{ Phytochemical Content (mg/g) } & \\
\hline & $\begin{array}{l}\text { Total } \\
\text { Phenols }\end{array}$ & Tannins & $\begin{array}{l}\text { Flavonoid } \\
\text { s }\end{array}$ & Saponins & Alkaloids \\
\hline $\begin{array}{l}\text { Piper } \\
\text { capense }\end{array}$ & $4.94 \pm 0.81$ & $\begin{array}{l}0.40 \\
0.07\end{array}$ & $\begin{array}{ll}1.72 \\
0.07\end{array}$ & $\begin{array}{l}35.08 \\
1.17\end{array}$ & $\begin{array}{l}4.67 \\
0.28\end{array}$ \\
\hline
\end{tabular}

Quantities are expressed as Mean \pm SD (Standard Deviation) of three samples for each extract. The expression of phytochemicals were $\mathrm{mg}$ per gram of lyophilate extract

Table 3: Quantitative screening of the phytochemicals in the medicinal plant extract.

Phytochemical analysis of the aqueous root extracts of Piper capense showed the presence of Saponins, Flavonoids, Alkaloids, Terpenoids and Tannins as indicated in Table 3.

\section{Discussion}

The study was carried out to invastigate the antidiabetic activity of aqueous root extract of Piper capense. The aqueous root extracts of Piper capense administered at five doses (25 mg per kilogram body weight $48.4 \mathrm{mg}$ per kilogram body weight, $93.5 \mathrm{mg}$ per kilogram body weight, $180 \mathrm{mg}$ per kilogram body weight, and $350 \mathrm{mg}$ per kilogram body weight) showed antidiabetic activity in diabetic mice. The antidiabetic activity shown was irrespective of the amount of the dose administered which suggest uptake of bioactive constituents through active transport which is saturable.

The plasma glucose decreasing effect of Piper capense root extracts may be due to the presence of phenols, alkaloids, flavonoids, sterols and tannins that have been shown to have hypoglycemic activity [18]. Inhibition of alpha-amylase and alpha-glucosidase enzymes is responsible for antidiabetic activity of condensed tannins which are extracted from some foods in kenya [19]. The epigllo-catechin-3gallate tannin also shows hypoglcemic activity as indicated by Broadhurst et al. [20,21]. Tannic acids commercially available induced phosphorylation of the insulin receptor (IR). It also helps in translocation of glucose transporter 4 (GLUT 4), which is the protein factors responsible for signaling pathway of insulin-mediated glucose transport [22]. Glauce et al. [23] reported that myricetin, a polyhydroxylated flavonol (flavonoid) has insulinomimetic properties and stimulate lipogenesis and transportation of glucose in the adipocytes hence lowering plasma glucose level [18].

The alkaloids indicated to be present in the aqueous root extract of Piper capense also have been reported to have antidiabetic activity. Berberine and tetrandine alkaloids are reported to show antioxidant activity which could be responsible for the different biological activities including antidiabetic activity. Also the alkaloid 1-ephedrine stimulates the regeneration of pancreas islets after the destruction of beta cells, this restores insulin secretion hence correcting hyperglycemia [18].
The aqueous root extract of Piper capense contained saponins. Saponins are shown to have antidiabetic activity. For instance, ginseng and its saponins have been shown to reduce plasma sugar in diabetic and normal mice [23]. Fractions of Saponin obtained from Momordica charantia decreased blood sugar levels and raised insulin secretion and synthesis of glycogen in alloxanised diabetic mice [24]. As reported by Chen and Zhang [25] saponins were shown to reduce serum glucose levels in elderly diabetic patients. Entada phaseoloides total saponins decreased fasted blood sugar significantly and reduced diabetic state associated oxidative stress in type two diabetic rats [26].

\section{Conclusion}

Administration orally of aqueous root extracts of Piper capense at $25 \mathrm{mg}$ per kilogram body weight, $48.4 \mathrm{mg}$ per kilogram body weight, $93.5 \mathrm{mg}$ per kilogram body weight, $180 \mathrm{mg}$ per kilogram body weight, and $350 \mathrm{mg}$ per kilogram body weight demonstrated antidiabetic activity without irrespective of the amount of dose administered. The antidiabetic activity demonstrated could be due to the phytochemicals in Piper capense. The administration of the extracts at the five doses did not show any adverse effects on the diabetic mice. The study confirms that aqueous extract of piper capense has antidiabetic activity however research should be carried to animals that are physiologically similar to human like apes.

\section{Acknowledgement}

The authors acknowledge the support of the entire staff of the Department of Biochemistry and Biotechnology, Kenyatta University, for their moral support. Thanks to Mr Chege Mwaura the traditional medical practitioners for the immense contribution in collecting the antidiabetic plants. We sincerely thank Mr James Adino of the Department of Medical Laboratory Sciences, Kenyatta University for technical assistance throughout the project.

\section{References}

1. WHO (1999). Definition, Diagnosis and Classification of Diabetes Mellitus and its Complications. Report of a WHO Consultation. Part 1: Diagnosis and Classification of Diabetes Mellitus. WHO, Geneva.

2. Davis SN, Granner DK (1996) Insulin, Oral Hypoglycemic Agents and the Pharmacology of Endocrine Pancreas. In: Goodman IS, Gilman AG (Editor) The Pharmacological Basis of Therapeutics (9th Edn), Mc-Graw Hill: New York, pp: 1487-1517.

3. American Diabetes Association (2007) "Diagnosis and classification of diabetes mellitus" Diabetes Care, 30: S42-47.

4. WHO (2006) Definition and Diagnosis of Diabetes Mellitus and Intermediate Hyperglycemia. Report of WHO/IDF consultation. WHO, Geneva.

5. Kerner W, Brückel J, German Diabetes Association ( 2014) Definition, classification and diagnosis of diabetes mellitus. Exp Clin Endocrinol Diabetes 122: 384-386.

6. Williams G, Pickup J (1991) New Drugs in the Management of Diabetes Mellitus. In: Pickup JC, Williams G (editors). Textbook of Diabetes. II Blackwell: Oxford, pp: 977-993.

7. Surendran S, Eswaran MB, Vijayakumar M, Rao CV (2011) In vitro and in vivo hepatoprotective activity of Cissampelos pareira against carbon tetrachloride induced hepatic damage. Indian J Exp Biol 49: 939-945.

8. Mahmood A, Mahmood A, Qureshi RA (2012) Antimicrobial activities of three species of family mimosaceae. Pak J Pharm Sci 25: 203-206.

9. Karau GM, Njagi ENM, Machocho AK, Wangai LN, Kamau PN (2012) Hypoglycemic Activity of Aqueous and Ethyl acetate Leaf And Stem Bark 
Citation: $\quad$ Njeri LK, Njagi ENM (2017) Anti-diabetic Activity in Mice of Piper Capence Used Traditionally in the Management of Diabetes Mellitus in Kenya. J Diabetes Metab 8: 737. doi:10.4172/2155-6156.1000737

Page 6 of 6

Extracts of Pappea capensis in Alloxan-Induced Diabetic BALB/C Mice. Brit J Pharmacol Toxicol 3: 251-258.

10. Piero NM, Njagi MJ, Kibiti MC, Ngeranwa JJN, Njagi NM, et al. (2012) Herbal management of diabetes mellitus: A rapidly expanding research avenue.

11. Parmar VS, Jain SC, Bisht KS, Jain R, Taneja P, et al. (1997) Phytochemistry of the genus Piper. Phytochemistry 46: 597-673.

12. Woguem V, Maggi F, Fogang HP, Tapondjoua LA, Womeni HM, et al. (2013) Antioxidant, antiproliferative and antimicrobial activities of the volatile oil from the wild pepper Piper capense used in Cameroon as a culinary spice. Nat Prod Commun 8: 1791-1796.

13. Lin VW, Cardenas DD (2003) Spinal cord medicine. Demos Medical Publishing, LLC: NY, USA, p: 251

14. John A (1989) 20th Century Words: Cambridge University Press.

15. Evans WE, Schentag JJ, Jusko WJ, Harrison H (1992) In: Evans WE, Schentag JJ (editors) Applied Pharmacokinetics: Principles of Therapeutic Drug Monitoring, (3rdedn). Vancouver.

16. Hosseinzadeh H, Younesi HM (2002) Antinociceptive and antiinflammatory effects of Crocus sativus L. stigma and petal extracts in mice. BMC Pharmacol 2: 7.

17. Houghton PJ, Raman A (1998) Laboratory Handbook for the Fractionation of Natural extracts. Chapman and Hall 154-187.

18. Middleton E Jr, Kandaswami C, Theoharides TC (2000) The effects of plant flavonoids on mammalian cells: Implications for inflammation, heart disease, and cancer. Pharmacol Rev 52: 673-751.
19. Kunyanga CN, Imungi JK, Okoth M, Momanyi C, Biesalski HK, et al. (2011) Antioxidant and antidiabetic properties of condensed tannins in acetonic extract of selected raw and processed indigenous food ingredients from Kenya. J Food Sci 76: C560-567.

20. Broadhurst CL, Polansky MM, Anderson RA (2000) Insulin like biological activity of culinary and medicinal plant aqueous extracts in vitro. J Agric Food Chem 48: 849-852.

21. Liu X, Kim JK, Li Y, Li J, Liu F, et al. (2005) Tannic acid stimulates glucose transport and inhibits adipocyte differentiation in 3T3-L1 cells. J Nutr 135: 165-171.

22. Viana GS, Medeiros AC, Lacerda AM, Leal LK, Vale TG, et al. (2004) Hypoglycemic and anti-lipemic effects of the aqueous extract from Cissus sicyoides. BMC Pharmacology 4: 9-12.

23. Kimura M, Suzuki J (1985) The pharmacological role of ginseng in the blend effect of traditional Chinese medicines in hyperglycemia. Advances of Chinese Medicinal Materials Research, World Scientific, Singapore.

24. Han C, Hui Q, Wang Y (2008) Hypoglycaemic activity of saponin fraction extracted from Momordica charantia in PEG/salt aqueous two-phase systems. Nat Prod Res 22: 1112-1119.

25. Chen KJ, Zhang WP (1987) Advances on antiageing herbal medicines in China. Abstracts of Chinese Medicine 1: 309-330.

26. Zheng T, Shu G, Yang Z, Mo S, Zhao Y (2012) Antidiabetic effect of total saponins from Entada phaseoloides ( L.) Merr. in type 2 diabetic rats. J Ethnopharmacol 139: 814-821. 